\title{
A study of the role and functions of inspectors of anatomy in South Africa
}

\author{
P Pillay, ${ }^{1}$ B Med Sci, H Med Sci, M Med Sci, PhD; D J McQuoid-Mason, ${ }^{2}$ BComm, LLB, LLM, PhD; K Satyapal, 'LRCP, LRCS, LM, MD, FICA, FRCP, LLM \\ 'Department of Clinical Anatomy, School of Laboratory Medicine and Medical Sciences, College of Health Sciences, University of KwaZulu-Natal, \\ Durban, South Africa \\ ${ }^{2}$ Centre for Socio-Legal Studies, Howard College School of Law, University of KwaZulu-Natal, Durban, South Africa
}

Corresponding author: P Pillay (Soobramoneypa@ukzn.ac.za)

\begin{abstract}
Inspectors of anatomy are supposed to monitor and regulate the use of human tissue for teaching and research purposes. In South Africa, provincial inspectors are appointed to oversee this function. However, there is a critical shortage of such persons, and there are only three inspectors currently appointed: one in an acting capacity for KwaZulu-Natal Province, and one each for the Gauteng and Western Cape provinces, respectively. It is imperative, therefore, that the appointment of inspectors of anatomy in the other provinces be addressed urgently. The responsibilities of inspectors of anatomy towards higher-education institutions are to: (i) maintain cadaver records; (ii) ensure that cadavers are obtained in a legal and ethical manner; (iii) carry out inspections of anatomy departments at least once a year; (iv) evaluate health and safety with regard to the storage of specimens; and (v) monitor cadaver procurement. This study recommends the establishment of a National Consultative Anatomy Forum to make decisions on: (i) the type of consent required for donations of bodies; (ii) the mechanisms for the donation of bodies for teaching and research; and (iii) the treatment of unclaimed and/or unidentified bodies. In addition, the forum should advise government on policy, and provide guidelines for the donation and use of cadavers and human tissue.
\end{abstract}

S Afr J Bioethics Law 2017;10(2):86-92. DOI:10.7196/SAJBL.2017.v10i2.619

A review of the legislation and regulations in South Africa (SA) has indicated that provision was made for the statutory appointment of inspectors of anatomy at different stages of SA history. However, there were significant changes between the Human Tissue Act No. 65 of $1983^{[1]}$ and the National Health Act No. 61 of $2003^{[2]}$ and its regulations.

In SA, provincial inspectors of anatomy are supposed to monitor and regulate institutions dealing with human tissue, as well as the general control of human bodies, tissue and organs for transplantation. ${ }^{[3]}$ However, they are not responsible for issues related to consent, governance and quality control. Therefore, human-tissue regulation by inspectors of anatomy should occur at each of the 11 departments of anatomy at higher-education institutions that are located in five of the provinces.

The functions of inspectors of anatomy at higher-education institutions include, inter alia, (i) ensuring that anatomists comply with legislation; (ii) inspecting departments of anatomy; (iii) examining cadaver records, registers or any other document at any time; and (iv) approving the removal and burial of cadavers and tissue from departments of anatomy. A recommendation from the Medico-Legal Symposium held in SA in 2011 was the establishment of national guidelines, with standardised national job descriptions for provincial inspectors of anatomy, and the establishment of an authority similar to the UK Human Tissue Authority ${ }^{[4]}$ to ensure continuity in the treatment of cadavers and tissue throughout the country. As the UK was the first country to appoint inspectors of anatomy under the Anatomy Act of $1832,{ }^{[5]}$ and since then has moved towards the appointment of the Human Tissue Authority, ${ }^{[4]}$ this study draws comparisons between the UK and SA in this respect.

\section{United Kingdom}

In the UK, the Anatomy Act of $1832,^{[5]}$ the Human Tissue Act of $1961^{[6]}$ and the Anatomy Act of $1984^{[7]}$ have all provided for inspectors of anatomy, with the fundamental role of regulating human tissue. As a result, the relevant health officials received constant reports from the inspectors, who monitored the use and procurement of cadavers that were used for anatomical teaching. ${ }^{[7]}$ The responsibilities of inspectors of anatomy were: (i) recommending approval of licencing for anatomical examinations; (ii) maintenance of records regarding the bodies donated, their storage and disposal; (iii) inspections and site visits of premises; (iv) ensuring appropriate consent was in place; and $(v)$ making sure that specimens were retained in accordance with legislation. ${ }^{[8,9]}$ Although the legislation set out the specific roles and responsibilities of such inspectors, their individual interpretations varied. On 1 April 2005, the post of inspector of anatomy was subsumed into the new regulatory department known as the Human Tissue Authority (HTA). ${ }^{[4]}$

The HTA was established under the UK Human Tissue Act of $2004,{ }^{[10]}$ arising from the public furore about the use of human tissue without consent. This regulatory body comprises of a committee of 16 members, who are neither scientists nor medical practitioners. ${ }^{[1]}$ The HTA regulates activities related to anatomical and postmortem examinations, transplantation and retention of human tissue for teaching and research. ${ }^{[12]}$ This is done by creating codes of practice. For example, Code 4 deals with anatomical examination, and Code 5 with the removal, storage, use and disposal of human organs and tissue. ${ }^{[13]}$ The HTA functions in a collaborative and consultative manner by working with medical and scientific groups and conducting public 
consultations. The roles of the HTA were: (i) the inspection and issuing of licences for anatomical and postmortem examinations; (ii) advice to the Secretary of State for Health; and (iii) formulating codes of practice that set out standard operating procedures and guidelines for the use of human tissue. ${ }^{[14]}$ The HTA recognises that consent is a fundamental requirement when using human tissue.

\section{South Africa}

The Anatomy Act No. 3 of $1911^{[15]}$ authorised inspectors of anatomy to regulate human tissue. From 1911 to 2002, legislation such as the Prisons Reformatories Prison Act No. 8 of 1959, ${ }^{[16]}$ the Anatomy Act No. 20 of $1959,{ }^{[17]}$ the Anatomical Donations and Post-mortems Act No. 24 of 1970, ${ }^{[18]}$ the Health Act No. 63 of $1977^{[19]}$ and the Human Tissue Act No. 65 of $1983^{[1]}$ all provided for the appointment of inspectors of anatomy to regulate human tissue procurement, storage, use and disposal. The inspectors also had sole power over unclaimed bodies found at public institutions that did not require postmortems. This allowed the inspectors to send such bodies to an authorised school of anatomy for dissection. ${ }^{[20]}$ The responsibilities of inspectors of anatomy were specified as: (i) distribution of bodies that were at their disposal to schools of anatomy; (ii) supervision of burial after 18 months; (iii) maintaining a register of all bodies sent to schools of anatomy; (iv) inspections; and (v) submission of a yearly report to the Minister of Education. ${ }^{[1,17-19]}$

Significant changes occurred with the introduction of the National Health Act No. 61 of 2003, ${ }^{[2]}$ from which the appointment and roles of inspectors of anatomy were omitted, although the act authorises the minister of health to introduce regulations governing the 'appointment and functions of inspectors of anatomy and investigating officers'. However, this has not yet been done. ${ }^{[21]}$ Although a detailed description of inspectors of anatomy is not included in the act, ${ }^{[2]}$ Chapter 10 establishes an inspectorate of health establishments with health officers appointed for each province.

\section{Regulations}

In 2011, regulations relating to the control of human bodies, tissue and blood products, ${ }^{[22]}$ and regulations relating to human tissue banks, were promulgated. ${ }^{[23]}$ These regulations stated that the head of a provincial department of health may appoint a provincial inspector of anatomy. The regulations also set out conditions for the appointment and duties of the inspector. However, in 2012, this responsibility was transferred from the head of the provincial department of health to the member of the executive council (MEC) responsible for health, and the latter was authorised to appoint a 'health officer' with the same powers and functions as an inspector of anatomy. ${ }^{[23]}$

According to the 2011 regulations regarding the control of human bodies, tissue, blood products and gametes, ${ }^{[22]}$ the stipulated period for an inspector of anatomy to be informed about an unclaimed body was within 30 days of death. ${ }^{[22]}$ The functions of the inspector include, inter alia: (i) ensuring compliance with the regulations; (ii) inspecting premises that have body or tissue products; (iii) examining the records, registers or any other documents at any time; and (iv) removing and burying the remains of a human body or tissue. ${ }^{[22]}$ Although the inspector of anatomy under the 2011 regulations regulated human bodies - and not blood and blood products - for teaching and research, the 2012 regulations describe the powers and functions of the 'repealed' inspector of anatomy as falling under the 'inspector of blood transfusion services.'[3] This suggests a need to re-evaluate the clearly defined definitions and role players referred to in the 2012 regulations. According to both sets of regulations, it is an offence if 'any person refuses or fails to comply to the best of her or his ability with any demand, requirement or order of an inspector of anatomy' or health officer. ${ }^{[22]}$

As seen from Table 1 below, there has been a change of name from 'inspector of anatomy' to 'health officer', but the appointment and functions of the health officer remain the same as those of the 'inspector of anatomy'. Section 68(1) of the National Health Act No. 61 of $2003^{[2]}$ allows the minister of health to make regulations regarding 'the appointment and functions of inspectors of the national bloodtransfusion service and progenitor cell-transplant institutions', as well as the appointment and functions of inspectors of anatomy. The 'inspector of blood transfusion service' is referred to in the 2012 regulations, but inspectors of anatomy are not. ${ }^{[24]}$ Although the term 'inspector of anatomy' is not referred to in the regulations, a vacancy was advertised for the post of 'inspector of anatomy' in 2015. ${ }^{[25]}$ This clearly demonstrates that there is ambiguity in the interpretation of 'inspectors of anatomy' and 'health officers', and this needs to be urgently amended.

This study was undertaken because in SA there are no previously documented studies on the roles, responsibilities, views and challenges of inspectors of anatomy related to the use of human tissue for teaching and research. In addition, the study draws comparisons, recommendations and lessons from the UK, because much of SA's early legislation on the topic was based on the UK experience, and there are still valuable lessons to be learned from it.

\section{Objectives}

The aim of this study was to document the role, responsibilities, views and challenges of inspectors of anatomy relating to the use of human tissue for teaching and research in SA. The appointments, qualifications, roles, responsibilities and challenges of the SA inspectors of anatomy were evaluated using semi-structured interviews.

\section{Research design and method}

The study used semi-structured interviews to obtain qualitative data. Participants were selected using purposive sampling, owing to the limited number of inspectors of anatomy in SA. This resulted in a small sample size, which is characteristic of qualitative research. However, the participants willingly provided valuable information in response to the research question, which contributed to the credibility of the study. Ethical clearance was obtained from the Biomedical Research Ethics Committee of the University of KwaZuluNatal (ref. no. BE 524/14).

Semi-structured interviews of 60 minutes each were conducted with the three existing provincial inspectors of anatomy in the Gauteng, KwaZulu-Natal and Western Cape provinces, and with one retired inspector from KwaZulu-Natal. Informed consent was obtained by providing participants with a letter detailing all the processes involved, together with the interview guides. A combination of open- and close-ended questions was used in the interview guide, which enabled the interviewees to elaborate on their answers where necessary. The one-on-one interactions enabled the researcher to ask in-depth questions to answer the research problems, and to explain the questions if further 
Table 1. Changes in the definition, appointment of and functions of inspectors of anatomy

\begin{tabular}{|c|c|c|c|c|}
\hline & 1983 & 2011 & 2012 & Comments \\
\hline Legislation & $\begin{array}{l}\text { Human Tissue Act No. } 65 \\
\text { of } 1983^{[1]}\end{array}$ & Government Notice R268 ${ }^{[3]}$ & $\begin{array}{l}\text { Government Notice } \\
\text { R180 }^{[24]}\end{array}$ & \\
\hline Definitions & $\begin{array}{l}\text { 'Inspector of anatomy' } \\
\text { means an inspector of } \\
\text { anatomy appointed as such } \\
\text { under section 29(1). }\end{array}$ & $\begin{array}{l}\text { 'Inspector of blood } \\
\text { transfusion services' } \\
\text { means an inspector of } \\
\text { blood transfusion services } \\
\text { appointed as such under } \\
\text { the Regulations Relating to } \\
\text { Blood and Blood Products. }\end{array}$ & $\begin{array}{l}\text { 'Health officer of blood } \\
\text { transfusion services' } \\
\text { means a health officer of } \\
\text { blood transfusion services } \\
\text { appointed by the minister in } \\
\text { terms of section } 80 \text {. }\end{array}$ & $\begin{array}{l}\text { An inspector of anatomy } \\
\text { does not regulate blood and } \\
\text { blood products; however, } \\
\text { the health officer of blood } \\
\text { transfusion can regulate } \\
\text { bodies. The definition in the } \\
\text { Human Tissue Act is most } \\
\text { suited. A suggestion is the } \\
\text { implementation of 'health } \\
\text { officer of anatomy'. }\end{array}$ \\
\hline $\begin{array}{l}\text { Method of } \\
\text { appointment }\end{array}$ & Director-General & $\begin{array}{l}\text { The provincial head of } \\
\text { department of health in } \\
\text { each province }\end{array}$ & The MEC in each province & $\begin{array}{l}\text { Change in method of } \\
\text { appointment. The Human } \\
\text { Tissue Act allowed for the } \\
\text { appointment of one or more } \\
\text { inspectors, while the NHA } \\
\text { allows for one appointment } \\
\text { per province. }\end{array}$ \\
\hline $\begin{array}{l}\text { Disposal of unclaimed } \\
\text { bodies }\end{array}$ & $\begin{array}{l}\text { The inspector of anatomy } \\
\text { controls the disposal of the } \\
\text { body of a destitute person } \\
\text { and bodies not claimed or } \\
\text { buried within } 24 \text { hours after } \\
\text { the death. The body may be } \\
\text { claimed by spouse, relative } \\
\text { or bona fide friend. }\end{array}$ & $\begin{array}{l}\text { The inspector of anatomy } \\
\text { controls the disposal of the } \\
\text { body of a deceased person } \\
\text { that is not buried, or claimed } \\
\text { for burial within } 30 \text { days } \\
\text { after the death. The body } \\
\text { may be claimed by spouse, } \\
\text { partner, any relative or bona } \\
\text { fide friend. }\end{array}$ & $\begin{array}{l}\text { The health officer controls } \\
\text { the body of a deceased } \\
\text { person that is not buried, } \\
\text { or claimed for burial within } \\
30 \text { days after the death. The } \\
\text { body may be claimed by } \\
\text { spouse, partner, major child, } \\
\text { parent, guardian, major } \\
\text { brother or major sister in the } \\
\text { specific order mentioned or } \\
\text { bona fide friend. }\end{array}$ & $\begin{array}{l}\text { The time period for the body } \\
\text { to be at the disposal of the } \\
\text { inspector has increased from } \\
24 \text { hours to } 30 \text { days.The } 2012 \\
\text { regulations contain a priority } \\
\text { list of persons who can act as } \\
\text { representatives. }\end{array}$ \\
\hline Notification & $\begin{array}{l}\text { If a body has not been } \\
\text { claimed/buried within } 24 \\
\text { hours after the death, notice } \\
\text { is sent to the inspector of } \\
\text { anatomy. }\end{array}$ & $\begin{array}{l}\text { If a body has not been } \\
\text { claimed/buried within } \\
30 \text { days after the death, } \\
\text { notice is sent to the } \\
\text { inspector of anatomy } \\
\text { concerned. }\end{array}$ & $\begin{array}{l}\text { If a body has not been } \\
\text { claimed/buried within } \\
30 \text { days after the death, a } \\
\text { direct notice is sent to the } \\
\text { health officer. }\end{array}$ & $\begin{array}{l}\text { Increase in period of } \\
\text { notification from } 24 \text { hours to } \\
30 \text { days. }\end{array}$ \\
\hline $\begin{array}{l}\text { Handing over of } \\
\text { bodies to institutions }\end{array}$ & $\begin{array}{l}\text { Upon receipt of the notice, } \\
\text { an inspector of anatomy } \\
\text { may by written order } \\
\text { directly hand the body over } \\
\text { to an institution. }\end{array}$ & $\begin{array}{l}\text { Upon receipt of the notice, } \\
\text { an inspector of anatomy } \\
\text { may by written order } \\
\text { directly hand the body over } \\
\text { to an institution. }\end{array}$ & $\begin{array}{l}\text { Upon receipt of the notice, } \\
\text { the health officer may } \\
\text { by written order directly } \\
\text { hand the body over to an } \\
\text { institution. }\end{array}$ & $\begin{array}{l}\text { Remains the same. Only } \\
\text { change is insertion of 'health } \\
\text { officer'. }\end{array}$ \\
\hline
\end{tabular}

information was required. ${ }^{[26]}$ The interviews were recorded in handwriting and on audiotape to ensure the accuracy of the data-capturing. The information was then transcribed by an independent transcriber.

The qualitative data were analysed by 'converting raw data into partially processed data. ${ }^{[26]}$ The data were analysed iteratively by moving backwards and forwards between data collection and analysis. Data were collected and analysed on an ongoing basis, enabling the researcher to identify themes. ${ }^{[2]}$ The themes were extracted through observation (seeing), coding (recognising something in it) and interpretation, and subsequently analysed. ${ }^{[28]}$

The data were validated by asking two of the interviewees to verify the themes generated, and to comment on the accuracy of the interpretation and conclusions drawn by the researcher. ${ }^{[26]}$ The scientific rigour of the data was established by using peer review, in which an external reviewer also read and critiqued the data and interpretations.

The themes that emerged from the data included: (i) the method of appointment of inspectors of anatomy; (ii) their functions; (iii) ethical issues they faced; (iv) the challenges they faced; and ( $v$ ) recommendations they made. For the purpose of this study, the inspectors of anatomy are referred to anonymously by numbers (i.e. inspectors 1, 2, 3 and 4.).

\section{The method of appointment of inspectors of anatomy}

The study showed that there were three male inspectors of anatomy and one female appointed in SA between 1994 and 2015. Prior to 2006, 
the posts were managed by the SA Police Services (SAPS). Since 2006, however, inspectors of anatomy have fallen under the management of the provincial departments of health forensic pathology services. The qualifications of the inspectors of anatomy varied, and at different stages have included: (i) a specialist pathologist; (ii) a dental practitioner with an honours degree in reproductive biology; (iii) a chief forensic pathologist; and (iv) a nursing education/occupational health practitioner.

The method of appointment as inspector of anatomy differed across the provinces. Inspectors 1 and 2 commented that they 'incidentally landed in the post' owing to specific interests in medical ethics, and were appointed by 'default'. Inspector 2 specified that 'as an occupational health practitioner, you are at the forefront if you are an inspector of anatomy'.

Inspector 1 indicated that in 2006, the provincial department of health assumed responsibility for the medicolegal services from SAPS. This resulted in the appointment of the provincial forensic pathologist in the additional role of inspector of anatomy. Inspector 3 stated that the post for the inspector of anatomy was advertised with a requirement of 'problem-solving' as a skill, as well as a background in the health sector. Inspector 4 stated that for his/her appointment, the nominations were made by the provincial department of health, since the post was a statutory appointment. Their levels of experience as inspectors of anatomy ranged from 5 years to 15 years.

\section{Functions of inspectors of anatomy}

The forensic services department in the provincial departments of health manage the post of inspector of anatomy. In one province, the inspector is also the chief forensic pathologist. The daily functions of inspectors of anatomy include co-ordinating the maintenance of the forensic services' mortuaries and performing investigations into unnatural deaths. The interviewees stated that their responsibilities towards higher education institutions are: (i) the maintenance of cadaver records; (ii) ensuring that cadavers are obtained in a legal and ethical manner; (iii) carrying out inspections of anatomy departments at least once a year; (iv) evaluating health and safety regarding the storage of specimens; and $(v)$ monitoring cadaver procurement.

Inspector 2 believed that his/her role was 'to ensure that [he] provide cadavers to departments of anatomy for learning purposes', while Inspector 1 declared that his/her role has 'changed since the advent of the National Health Act, whereas under the Human Tissue Act their [duties were] quite specific regarding the monitoring of the whole of anatomy'.

Inspector 3 is the only inspector of anatomy without a dual function, and this individual's priority is human-tissue regulation. His/her daily functions include: (i) dealing with exhumations; (ii) authorising the import and export of human remains; (iii) ensuring appropriate ethical conduct when research related to cadaveric or living tissue is performed at a hospital or higher-education institution; (iv) monitoring donations of human tissue; ( $v$ ) advising hospital personnel on dealing with unclaimed or unidentified bodies; (vi) carrying out inspections of hospitals, biobanks, mortuaries, or any place that holds human tissue; (vii) investigating complaints related to the use of human tissue; and (viii) developing policies related to human tissue.
The inspectors recognised that the current legislation, the National Health Act, is not as comprehensive regarding the functions of an inspector of anatomy as the repealed Human Tissue Act, because the latter was much more precise in this regard. The 2012 regulations of the National Health Act introduced the term 'health officer, ${ }^{[24]}$ but did not define the term adequately. To date, no new regulations describing the appointment and function of inspectors of anatomy have been promulgated.

Inspector 1 noted the following:

'In reading the terms and conditions of the functions in the National Health Act, the act itself does not talk to the regulations, so we don't know where we stand in terms of regulations. There is reference to a 'health officer' but no clear-cut definition of what a health officer is. Traditionally, an inspector used to be a medical practitioner.'

Inspector 4 suggested that the National Health Act should define and incorporate the role of inspectors of anatomy into the legislation. It was further stated that the current inspectors 'need to be aware of all the regulations'.

Inspector 2 believed that the National Health Act 'build-up is perfect regarding process and procedure for donation'. However, the inspector stated that the legislation was inadequate on many issues: $(i)$ the act does not allow the use of human tissue within 24 hours of death for the training of surgical specialities; (ii) the time period allocated to the identification of unclaimed bodies is too short; and (iii) the management of the identification process needs to be addressed.

According to the National Health Act, the introduction of the Office of Health Standards does not include a specific reference to inspectors of anatomy. Instead it refers to inspectors related to health-systems management. In the words of Inspector 2:

'This leaves the inspector of anatomy virtually on their own, and means at the provincial level you need a person that understands the crisis and can drive the agenda at national level.'

Inspector 3 stated that the National Health Act regulations extended the work of the environmental health officers 'without the actual competence.' Inspector 1 stated that repatriation of human tissue is overseen by the environmental-health officer, which poses a challenge to the inspector of anatomy, since all human tissue may not be adequately monitored.

Since the appointment of inspectors of anatomy is a statutory position, an inspector is expected to submit annual year-end reports to the MEC responsible for health. In addition, the inspectors must ensure compliance with the law at hospitals and higher-education institutions in their designated provinces.

According to Inspector 4, prior to the passing of the National Health Act, unclaimed and unidentified bodies were the property of the state, and managed by the relevant inspector of anatomy. Instead of a pauper burial, these bodies were donated by the inspectors of anatomy to departments of anatomy. Unclaimed indigent bodies (i.e. bodies of the poor and families experiencing financial constraints) are often not claimed either by the family or a friend of the deceased. The families of unclaimed bodies of indigent persons are encouraged to donate such bodies to departments of anatomy in the provinces concerned. The departments of anatomy cover the costs of the transportation and disposal of the bodies once the academic year is completed. Once the inspector of anatomy approves the donation, the bodies are sent to a designated department of anatomy. 


\section{Ethical issues faced by inspectors of anatomy}

Inspector 1 suggested that the practice of sending an unclaimed and unidentified pauper body to a department of anatomy is 'most problematic as it results in ethical dilemmas'. The ethical dilemma arises because consent is not possible in these cases. Inspector 1 stated that their role was that of a 'custodian of ethics and law'. In contrast, another inspector posed the rhetorical question: 'Whose ethics? Is it my ethics or your ethics or our personal beliefs?' This inspector mentioned that by 'treating the body with respect and dignity, you are working within an ethical framework'.

Inspector 1 further stated that:

'[if] pauper burials are the solution to all unclaimed and unidentified bodies at hospitals and mortuaries, then where is the dignity and respect if you have five bodies buried together in an unmarked common grave? The exhumation process for the purpose of identification does not afford dignity to all the bodies in that particular pauper grave.

Inspector 1 believes that the humane way of dealing with an unclaimed and unidentified body is to send the body to a department of anatomy, to be embalmed and stored for a period of time, with processes in place to identify the body.

Inspector 2 suggested that in the event of a pauper burial, there should be an awareness of the cultural background of the deceased. In addition, there should be a proper method of identifying an unclaimed and unidentified body. Moreover, those who cannot afford the burial should be encouraged to donate the body to a department of anatomy. Inspector 2 indicated that there was a need for discussions with the public, media, anatomists and legal representatives on a way forward.

In this regard, Inspector 3 stated:

'Human tissue of the unclaimed can be used as long as the body is treated with dignity and the body can be claimed at any time. If it is incorrect to use pauper bodies due to ethical reasons, then whose ethics? Ethics changes from person to person. If it is unethical, what is the solution? I make sure the regulations are known to hospitals. Therefore, hospital personnel inform me, the inspector of anatomy, if there is an unclaimed or unidentified body. The family of the unclaimed body is given the choice of either having a pauper burial or donating their body to an anatomy department.'

\section{Challenges faced by inspectors of anatomy}

Some of the challenges experienced by the inspectors of anatomy are: (i) the management of tissue at higher-education institutions; (ii) the issue of the legality of departments of anatomy in provinces with no inspector; (iii) the dual functions of inspectors; (iv) provincial inspectors working in silos; $(v)$ the failure to define the post of inspector of anatomy in the National Health Act; (vi) the fact that some hospitals are not'pro-donation' in certain provinces; (vii) the absence of standard operating procedures or guidelines for all provinces; and (viii) the failure to have all human tissue monitored by one authority.

\section{Recommendations made by the inspectors of anatomy}

The inspectors of anatomy made the following recommendations:

- An inspector of anatomy appointee should be someone with a medical or surgical background.
- In order for the appointee to function optimally, there should be no dual functioning of an inspector.

- Heads of departments of anatomy should be held accountable for human tissue that is used for teaching and research, and required to monitor the cadaver records and understand the law.

- There need to be benchmarks of the functions of inspectors of anatomy, and guidelines and uniform standard operating procedures promulgated.

- If the inspector of anatomy's interpretation of the law differs from those of others, the inspector should consult the stipulated regulations, as they provide guidance for the necessary adherence.

- An inspector of anatomy should be appointed in every province where there is a department of anatomy, biobank or any other institution dealing with human tissue.

\section{Discussion}

A review of the legislation and regulations in SA indicated that there has been provision for the appointment of inspectors of anatomy at different stages of SA history. At present, the implementation of the use of or procurement of cadavers, in terms of the National Health Act and its regulations, falls under the jurisdiction of the inspector of anatomy in the respective provinces.

The National Health Act regulations state that approval for the use of unclaimed indigent bodies must be authorised by a written order from an inspector. ${ }^{[24]}$ However, the notice period for this to occur may be short. Furthermore, the regulations relating to the management of human remains ${ }^{[29]}$ state that unclaimed bodies are to be disposed of according to the regulations regarding the rendering of the forensic pathology service. ${ }^{[30]}$ These state that the body of an unclaimed and unidentified person must be stored in a freezer within 7 days of death, and that if the body remains unidentified for 30 days, the local municipality must provide a pauper burial or cremation for the body. ${ }^{[31]}$ The regulations relating to the general control of human bodies, tissue and organs for transplantation, however, state that the body of a deceased person that is not buried, or claimed for burial within 30 days, is at the disposal of the health officer in whose area the body is located. ${ }^{[24]}$

A review of the roles and responsibilities of inspectors of anatomy in the UK, compared with their role in SA revealed that in the UK, their posts have been incorporated into the HTA. Table 2 shows the comparison between the HTA and the inspector of anatomy and/or health officer in SA.

The HTA deals with: (i) consent; (ii) the donation of bodies for anatomical examination; (iii) guidance and standard operating procedures for persons working in anatomy; (iv) licensing; and ( $v$ ) the inspection of the use of bodies and tissue in research and education by medical organisations. ${ }^{[12-14]}$ Furthermore, the HTA authorises the storage and anatomical examination of bodies, provided that this is carried out by or under the direction of a 'designated individual'. In $\mathrm{SA}$, inspectors of anatomy regulate the general control of human bodies, tissue and organs for transplantation, and do not stipulate the standards related to consent, governance and quality control.

The interviews with the inspectors of anatomy revealed that there were two inspectors of anatomy fully appointed, and one in an acting capacity, in only three of the nine provinces of SA. In the provinces with no inspectors of anatomy, their role may be carried out by the forensic pathology services. The background, experience 
Table 2. Summary of UK Human Tissue Authority v. SA inspector of anatomy

\begin{tabular}{|c|c|c|}
\hline & Human Tissue Authority (UK) & Inspector of anatomy (SA)/health officer \\
\hline Legislation & Human Tissue Act of $2004^{[10]}$ & National Health Act No. 61 of $2003^{[2]}$ \\
\hline Relevant section & Code 4: Anatomical Examination & Regulations \\
\hline Method of appointment & Regulatory body with 16 lay persons & Provincial inspector of anatomy/health officer \\
\hline Background/expertise & Non-medical and non-scientist & $\begin{array}{l}\text { Medical person or with medical-related background with } \\
\text { some knowledge of law and medical ethics }\end{array}$ \\
\hline Framework & Provide advice and guidance & Regulation of human tissue \\
\hline Scope of the post & $\begin{array}{l}\text { Code } 4 \text { allows the donation of whole bodies for anatomical } \\
\text { examination (with consent) and for the storage and } \\
\text { anatomical examination of a body; provides guidance and } \\
\text { standard operating procedures for persons working in } \\
\text { anatomy }\end{array}$ & $\begin{array}{l}\text { Regulations regarding the general control of human } \\
\text { bodies, tissue and organs for transplantation }\end{array}$ \\
\hline Responsibility & $\begin{array}{l}\text { The remit includes the removal, storage and use of human } \\
\text { bodies, import and export of human bodies and the } \\
\text { disposal of human tissue; inspecting and issuing licences } \\
\text { to establishments; preparation of codes of practice setting } \\
\text { out standards; providing advice to the Secretary of State } \\
\text { for Health and the public }\end{array}$ & $\begin{array}{l}\text { Variable in provinces: according to legislation, inspectors } \\
\text { of anatomy must (i) ensure compliance with the } \\
\text { regulations; (ii) inspect premises that have body or tissue } \\
\text { products; (iii) examine the records, registers or any other } \\
\text { documents at any time; and (iv) remove and bury the } \\
\text { remains of human bodies or tissue }\end{array}$ \\
\hline $\begin{array}{l}\text { Establishment of } \\
\text { standards }\end{array}$ & $\begin{array}{l}\text { Consent is the overriding principle for activities involving } \\
\text { the use of human tissue; tissue taken should be treated } \\
\text { with respect and the dignity of the person be maintained } \\
\text { at all times; the standards are consent, governance and } \\
\text { quality systems, premises, facilities and equipment, and } \\
\text { disposal of bodies or tissue }\end{array}$ & $\begin{array}{l}\text { Not clearly established in regulations, as those relating to } \\
\text { inspectors of anatomy have not yet been promulgated }\end{array}$ \\
\hline
\end{tabular}

and responsibilities of the inspectors of anatomy vary across the different provinces. Although inspectors of anatomy are present in some provinces, there are higher-education institutions in SA that are facing critical cadaver shortages owing to ethical constraints. In two provinces, the inspectors of anatomy play an integral role in assisting departments of anatomy to procure cadaveric material.

It was suggested at a medicolegal symposium held in SA in 2011 that national guidelines should be established, with a standardised national job description, for provincial inspectors of anatomy. The suggestion was also made that police officers should be deputised as human-tissue inspectors where there were no inspectors of anatomy. ${ }^{[32]}$ However, the recommendations from the inspectors of anatomy interviewed in the study are that persons with a medical qualification, knowledge of ethics and the law and the ability to solve problems would be ideal candidates for appointment. One of the other problems highlighted during the interviews was the issue of the dual functions of inspectors, and the need for this to be addressed. In order to achieve this, however, the roles and responsibilities of inspectors of anatomy need to be clearly defined in the regulations that in terms of the National Health Act should be promulgated by the minister of health. ${ }^{[23]}$

According to the National Department of Health, the main function of an inspector of anatomy is 'to ensure compliance in regards to handling, donation, transportation, use, disposal, import and export of human tissue.[33] The inspectors interviewed during the study all emphasised the need to delineate their functions, because their job descriptions often differed from their daily tasks. Owing to varying ethical perceptions by the inspectors regarding the use of bodies and tissue for anatomical teaching and research, there is a need for clear regulations to be promulgated.

\section{Conclusion and recommendations}

The roles and functions of the inspectors of anatomy in their respective provinces differed from their daily tasks. Some of the challenges experienced by the inspectors of anatomy were: (i) the management of tissue at higher-education institutions; (ii) the dual functions of inspectors of anatomy; (iii) provincial inspectors working in silos; (iv) the failure to define the post of inspector of anatomy in the National Health Act; $(v)$ hospitals not being 'pro-donation' in certain provinces; ( $v i$ ) the absence of a standard operating procedure or guidelines for all provinces; and (vii) the failure to have all human tissue monitored by one authority.

The study demonstrated that inspectors of anatomy play a major role in the regulation of human tissue in SA. Therefore, it is imperative that the appointment of inspectors of anatomy in all provinces be addressed urgently. The National Health Act allows the minister of health to make regulations related to the appointment and functions of inspectors of anatomy; however, these have not yet been promulgated. Clarity regarding the nomenclature used is required. In addition, the formation of provincial and national guidelines, together with standard operating procedures, should be introduced by the provincial health authorities.

The study showed that inspectors of anatomy play a major role in the regulation of human tissue in SA. Therefore, it is imperative that the issue of the appointment of inspectors of anatomy in all provinces be addressed urgently. In addition, clarity with regard to the nomenclature used is required. Provincial health authorities should introduce provincial and national guidelines, together with standard operating procedures, for anatomists. Given the concerns of the inspectors of anatomy interviewed, and what the study has shown regarding the operation of the UK HTA, it is submitted that 
a national consultative anatomy forum should be established to make decisions on: (i) issues of consent; (ii) the donation of bodies for teaching and research; and (iii) the use of unclaimed and/or unidentified bodies. Such a forum could also advise the minister of health on questions of policy, the promulgation of the necessary regulations and the need for standard operating procedures. The forum would operate as an overarching body that incorporates key role players, including the inspectors of anatomy, together with representation from anatomists, academics, legal advisors and other relevant stakeholders. It is necessary that such a forum would be fully inclusive of the belief systems of the diverse SA population, as well as being aimed at improving the quality of anatomical teaching and research in the country.

Acknowledgements. The authors would like to thank the inspectors of anatomy for their participation and contributions to this article through their interviews.

Author contributions. PP contributed to the design and implementation of the research, to the analysis of the results and to the writing of the manuscript. DMM and KS provided critical feedback and helped shape the research, analysis and manuscript.

Funding. None.

\section{Conflicts of interest. None.}

1. South Africa. Human Tissue Act No. 65 of 1983.

2. South Africa. National Health Act No. 61 of 2003

3. South Africa. National Health Act of 2003. Regulations regarding the control of human bodies, tissue, blood products and gametes. Government Gazette No. 34159 2011. (Published under Government Notice R268). https://www.gov.za/sites/www. gov.za/files/334159_gon268.pdf (accessed 4 July 2016).

4. Human Tissue Authority. HTA Codes of Practice and Standards. London: HTA, July 2006. https://www.hta.gov.uk/guidance-professionals/codes-practice (accessed 15 January 2016).

5. United Kingdom. Anatomy Act of 1832.

6. United Kingdom. Human Tissue Act of 1961.

7. United Kingdom. Anatomy Act of 1984.

8. Riederer BM, Bolt SH, Brenner E, et al. The legal and ethical framework governing body donation in Europe - 1st update on current practice. Eur J Anat 2012;16(1):1-21.

9. MacDonald $\mathrm{H}$. The anatomy inspector and the government corpse. Hist Aus 2010;6(2):40-41. https://doi.org/10.2104/ha090040

10. United Kingdom. Human Tissue Act of 2004.

11. McHale J. The Human Tissue Act 2004: Innovative legislation - fundamentally flawed or missed opportunity? Liverp Law Rev 2005;26(2):169. https://doi.org/10.1007/ s10991-005-4842-7

12. Human Tissue Authority. HTA Code of Practice 4 - Anatomical Examination. London HTA, July 2006. https://www.hta.gov.uk/guidance-professionals/codes-practice (accessed 15 January 2016).
13. Human Tissue Authority. HTA Code of Practice 5-Disposal of human tissue. London: HTA 2016. https://www.hta.gov.uk/sites/default/files/Code_of_practice_5_Disposal_of_human_tissue.pdf (accessed 15 January 2016).

14. Human Tissue Authority. HTA Codes and Standards. https://www.hta.gov.uk/ sites/default/files/Code\%20C\%20-\%20Anatomy\%20Final_0.pdf (accessed 15 January 2017).

15. South Africa. Anatomy Act No. 3 of 1911.

16. South Africa. Prisons Act No. 8 of 1959. Section 35. Prisons and Reformatories.

17. South Africa. Anatomy Act No. 20 of 1959. Section 6(1)(a).

18. South Africa. Anatomical Donations and Post-mortems Act No. 24 of 1970.

19. South Africa. Health Act No. 63 of 1977. Section 48(2).

20. South Africa. Human Tissue Act No. 65 of 1983. Section 29(1).

21. South Africa. National Health Act No. 61 of 2003. Section 68(1)(m).

22. South Africa. National Health Act of 2003. Regulations regarding the control of human bodies, tissue, blood products and gametes. Government Gazette No. 34159, 2011. (Published under Government Notice R268). https://www.gov.za/sites/www. gov.za/files/334159 gon268.pdf (accessed 4 July 2016).

23. South Africa. National Health Act of 2003. Regulation 5 of the Regulations regarding human tissue banks. Government Gazette No. 34159, 2011. (Published under Government Notice R267). https://www.greengazette.co.za/documents/regulationgazette-34159-of-01-apr-2011-vol-550-no-9511_20110401-GGR-34159 (accessed 4 July 2016)

24. South Africa. National Health Act of 2003. Regulation 20(1) of the Regulations regarding human tissue banks. Government Gazette No. 35099, 2012. (Published under Government Notice R180). http://www.saflii.org/za/legis/consol_reg/ nha6102003rangnr180590.pdf (accessed 4 July 2016).

25. National Department of Health, South Africa. SA Government Vacancy: Inspector of Anatomy. http://sa-government-vacancies.blogspot.com/2015/04/vacancyinspector-of-anatomy.html (accessed 27 July 2017).

26. Teddlie C, Tashakkori A. Foundations of Mixed Methods Research: Integrating Quantitative and Qualitative Approaches in the Social and Behavioural Sciences. Thousand Oaks, CA: Sage, 2009

27. Patton MQ. Qualitative Evaluation and Research Methods (3rd ed.). Thousand Oaks, CA: Sage, 2002.

28. Eisner EW. The Enlightened Eye: Qualitative Inquiry and the Enhancement of Educational Practice. Upper Saddle, NJ: Merrill, 1998.

29. South Africa. National Health Act of 2003. Regulations relating to management of human remains. Government Gazette No. 30075, 2007. (Published under Government Notice R636). www.saflii.org/za/legis/consol_reg/nha61o2003rangnr363590.pdf (accessed 4 July 2016)

30. South Africa. National Health Act of 2003. Regulations regarding the rendering of the forensic pathology service. Government Gazette No. 30075, 2007. (Published under Government Notice R636). www.saflii.org/za/legis/consol_reg/ nha6102003rangnr636590.pdf (accessed 4 June 2016).

31. South Africa. National Health Act of 2003. Regulation 32 of the Regulations regarding the rendering of the forensic pathology service. Government Gazette No. 30075, 2007. (Published under Government Notice R636). www.saflii.org/za/legis/consol_ reg/nha61o2003rangnr636590.pdf (accessed 4 June 2016).

32. McQuoid-Mason D. UKZN anniversary symposium on the medicolegal and ethical implications of human tissue use. S Afr J Bioethics Law 2011;294(1):13-44.

33. Department of Health, Provincial Government of Western Cape, South Africa. Forensic Pathology Services Newsletter. Up Close and Personal: Ryan Clayton Inspector of Anatomy. Cape Town: Provincial DoH, Western Cape: June/July 2011:2. https://www.westerncape.gov.za/Other/2011/12/fps_newsletter_3.pdf (accessed 2 June 2016).

Accepted 17 October 2017 